\title{
Improvement in exercise haemodynamics by isosorbide dinitrate in patients with severe congestive cardiac failure secondary to ischaemic heart disease
}

\author{
JOHN STEPHENS, JOHN CAMM, AND ROWORTH SPURRELL \\ From the Department of Cardiology, St. Bartholomew's Hospital, London
}

SUMMARY Seven patients with severe chronic congestive cardiac failure secondary to ischaemic heart disease performed submaximal supine exercise before and after $5 \mathrm{mg}$ sublingual isosorbide dinitrate at the time of cardiac catheterisation. Exercise before isosorbide dinitrate produced a poor response in left ventricular performance. After isosorbide dinitrate this response was significantly improved. Compared with the control exercise period, cardiac index increased from mean 2.6 to $3.1 \mathrm{l} / \mathrm{min}$ per $\mathrm{m}^{2}$ $(P<0.0025)$, stroke volume index from mean 22 to $27 \mathrm{ml} / \mathrm{m}^{2}(P<0.0025)$, and left ventricular stroke work index from mean 21 to $30 \mathrm{~g} \mathrm{~m} / \mathrm{m}^{2}(P<0.01)$. Mean left ventricular filling pressure fell from 37 to $26 \mathrm{mmHg}(\mathrm{P}<0.01)$.

Although isosorbide dinitrate reduced left ventricular filling pressure at rest from mean 26 to 17 mmHg $(P<0.005)$, there was no significant change in mean cardiac index or stroke volume index, while left ventricular stroke work index decreased from mean 29 to $22 \mathrm{~g} \mathrm{~m} / \mathrm{m}^{2}(P<0.05)$.

Isosorbide dinitrate effectively reduces left ventricular filling pressure in the resting patient with congestive cardiac failure but produces a more comprehensive improvement in left ventricular performance during exercise.

Vasodilating agents have been shown to improve left ventricular performance in patients with congestive cardiac failure after acute myocardial infarction (Gold et al., 1972; Chatterjee et al., 1973; Bussmann et al., 1977) and with chronic congestive cardiac failure (Majid et al., 1971; Guiha et al., 1974; Miller et al., 1975; Rossen et al., 1976). Of the orally available agents, isosorbide dinitrate has been shown to be effective in reducing left ventricular filling pressure in congestive cardiac failure for 4 to 5 hours after administration (Franciosa et al., 1974; Williams et al., 1977). Sublingual isosorbide dinitrate appears to be effective in this respect for $1 \frac{1}{2}$ hours (Gray et al., 1975). In the ambulant patient with congestive cardiac failure an important therapeutic objective is the improvement of his exercise tolerance. This study was designed to assess further the possible usefulness of long-term treatment with isosorbide dinitrate in this respect.

Received for publication 24 November 1977.

\section{Patients and methods}

Seven patients with chronic congestive cardiac failure undergoing cardiac catheterisation were studied. Severe exertional dyspnoea was the predominant symptom, though angina pectoris was a feature in some. All were receiving treatment with large doses of diuretics. In addition, some patients were receiving digoxin. Chest $x$-ray films showed cardiomegaly and upper lobe blood redistribution in all patients. The aetiology of the congestive cardiac failure was judged to be ischaemic heart disease in all on historic and electrocardiographic evidence (Table 1). Forty-eight hours before cardiac catheterisation digitalis therapy was withdrawn. Diuretic therapy was continued. Premedication was with diazepam $10 \mathrm{mg}$. Informed consent was obtained in all cases. Left ventricular angiography was performed in the right anterior oblique position via a right brachial arteriotomy using a NIH catheter. Coronary arteriography was subsequently performed in 6 patients. A thermodilution catheter was advanced to the pulmonary 
Table 1 Patient data

\begin{tabular}{|c|c|c|c|c|c|c|}
\hline $\begin{array}{l}\text { Case } \\
\text { No. }\end{array}$ & $\begin{array}{l}\text { Age and } \\
\text { sex }\end{array}$ & Presenting symptom & Electrocardiogram & $\begin{array}{l}\text { Level of } \\
\text { exercise } \\
\text { (kpm) }\end{array}$ & $\begin{array}{l}\text { Coronary arteriogram } \\
\text { No. of vessels with } \\
>50 \% \text { stenosis }\end{array}$ & $\begin{array}{l}\text { Left ventricular } \\
\text { ejection fraction } \\
(\%)\end{array}$ \\
\hline $\begin{array}{l}1 \\
2 \\
3 \\
4 \\
5 \\
6 \\
7\end{array}$ & $\begin{array}{l}65 \mathrm{M} \\
58 \mathrm{M} \\
67 \mathrm{M} \\
50 \mathrm{M} \\
52 \mathrm{M} \\
57 \mathrm{M} \\
45 \mathrm{~F}\end{array}$ & $\begin{array}{l}\text { Dyspnoea, angina } \\
\text { Dyspnoea, angina } \\
\text { Dyspnoea } \\
\text { Dyspnoea } \\
\text { Dyspnoea } \\
\text { Dyspnoea, angina } \\
\text { Dyspnoea }\end{array}$ & $\begin{array}{l}\text { Old DMI, old AMI } \\
\text { Diffuse ST-T changes } \\
\text { Old DMI, old AMI } \\
\text { Old AMI } \\
\text { Old DMI, old AMI } \\
\text { Old DMI, old AMI } \\
\text { Old AMI }\end{array}$ & $\begin{array}{r}75 \\
75 \\
150 \\
75 \\
150 \\
75 \\
75\end{array}$ & $\begin{array}{l}3 \\
3 \\
2 \\
\text { Not performed } \\
3 \\
3 \\
1\end{array}$ & $\begin{array}{l}24 \\
31 \\
21 \\
32 \\
18 \\
17 \\
19\end{array}$ \\
\hline
\end{tabular}

Abbreviations: AMI, anterior myocardial infarction; DMI, diaphragmatic myocardial infarction.

artery. Pressures were measured using Bell and Howell transducers with zero set at mid-chest and recorded on a Mingograf 82 recorder at paper speeds of $25 \mathrm{~mm} / \mathrm{s}(50 \mathrm{~mm} / \mathrm{s}$ for left ventricular pressure). Cardiac output was measured in triplicate $^{1}$ by the thermodilution technique (Ganz and Swan, 1972) using a Waters cardiac output computer.

After completion of the angiograms, a 40-minute rest period was allowed. Previous studies indicate that this is an adequate period for recovery from the effects of angiographic contrast material (Mullins et al., 1972). Control recordings of heart rate, pulmonary arterial and left ventricular pressures, and cardiac output were made. The patient then performed supine leg exercise on a bicycle ergometer at a submaximal work rate (determined on a separate occasion before catheterisation) for a period of $2 \frac{1}{2}$ to 3 minutes, after which time recordings were repeated. Exercise was discontinued and a 5-minute rest period allowed. Isosorbide dinitrate, $5 \mathrm{mg}$, was then administered sublingually after a second series of control recordings. Ten minutes after isosorbide dinitrate administration recordings were repeated at rest and during exercise at the same work rate and for the same time as before.

Left ventricular end-diastolic pressure was measured at the intercept of the downstroke of the ' $a$ ' wave and the upstroke of the left ventricular pressure curve averaged for 10 beats. The time from the onset of the upstroke of the curve to the point on its downstroke where left ventricular pressure was equal to the left ventricular end-diastolic pressure was taken to represent the left ventricular ejection period. ${ }^{2}$ Mean left ventricular systolic pressure was obtained by dividing the area between these points by the left ventricular ejection period. Left ventricular stroke work index, $\mathrm{g} \mathrm{m} / \mathrm{m}^{2}=$ (mean

${ }^{1}$ Technically unsatisfactory thermal curves were repeated giving $<10$ per cent variation in values accepted.

'This slightly overestimates left ventricular ejection period derived from the aortic pressure trace. left ventricular systolic pressure-left ventricular end-diastolic pressure) $\times$ stroke volume index $\times$ 0.0136 . Tension-time index, $\mathrm{mmHg} \mathrm{s} / \mathrm{min}=$ left ventricular area $\times$ heart rate. Left ventricular ejection fraction was calculated from the left ventricular cineangiogram (Sandler and Dodge, 1968).

\section{Results}

CINEANGIOGRAPHIC DATA (Table 1)

Left ventricular cineangiography showed severe reduction in ejection fraction in all patients. The contraction pattern was diffusely abnormal in all patients, there being no areas where motion was paradoxical, i.e. aneurysmal.

Coronary arteriography showed significant stenosis of one or more major coronary arterial branches in all 6 patients in whom this was performed.

\section{HAEMODYNAMIC DATA}

Effects of exercise (Table 2)

The degree of exercise achieved was modest (75 to $150 \mathrm{kpm}$-Table 1). The resting left ventricular end-diastolic pressure was greater than $16 \mathrm{mmHg}$ in all but one patient. Supine exercise was associated with a 29 per cent increase in mean heart rate. Changes in cardiac index and stroke volume index were variable, increasing in some patients and decreasing in others, there being no change in mean values. Mean left ventricular end-diastolic pressure and mean pulmonary arterial pressures rose significantly (57\% and $48 \%$, respectively). Left ventricular stroke work index increased in some patients and decreased in others, there being no change in the mean. Mean tension-time index rose by 18 per cent. Mean left ventricular systolic pressure did not change significantly.

\section{Effects of isosorbide dinitrate on resting haemodynamics (Table 3)}

The principal haemodynamic effect of isosorbide 
Table 2 Haemodynamic effects of exercise

\begin{tabular}{|c|c|c|c|c|c|c|c|c|c|c|c|c|c|c|c|c|}
\hline \multirow{2}{*}{$\begin{array}{l}\text { Case } \\
\text { No. }\end{array}$} & \multicolumn{2}{|l|}{$H R$} & \multicolumn{2}{|l|}{$C I$} & \multicolumn{2}{|l|}{$S V I$} & \multicolumn{2}{|c|}{$M P A$} & \multicolumn{2}{|c|}{ LVSP } & \multicolumn{2}{|c|}{$L V E D P$} & \multicolumn{2}{|c|}{$L V S W I$} & \multicolumn{2}{|l|}{$T T I$} \\
\hline & $R$ & $E$ & $\boldsymbol{R}$ & $E$ & $R$ & $E$ & $\boldsymbol{R}$ & $E$ & $\boldsymbol{R}$ & $E$ & $R$ & $E$ & $\boldsymbol{R}$ & $E$ & $R$ & $E$ \\
\hline $\begin{array}{l}1 \\
2 \\
3 \\
4 \\
5 \\
6 \\
7 \\
\text { Mean } \\
\pm \text { SEM }\end{array}$ & $\begin{array}{r}90 \\
70 \\
100 \\
86 \\
90 \\
100 \\
103 \\
91 \\
4.6\end{array}$ & $\begin{array}{r}135 \\
115 \\
130 \\
97 \\
115 \\
110 \\
120 \\
117 \\
5 \cdot 2 \\
<0.0025\end{array}$ & $\begin{array}{l}2 \cdot 1 \\
3 \cdot 0 \\
2 \cdot 7 \\
1 \cdot 7 \\
1 \cdot 8 \\
2 \cdot 1 \\
2 \cdot 8 \\
2 \cdot 3 \\
0 \cdot 2\end{array}$ & $\begin{array}{l}2 \cdot 4 \\
3 \cdot 6 \\
2 \cdot 5 \\
1 \cdot 2 \\
2 \cdot 9 \\
2 \cdot 4 \\
3 \cdot 2 \\
2 \cdot 6 \\
0 \cdot 3 \\
\text { NS }\end{array}$ & $\begin{array}{c}23 \\
43 \\
27 \\
20 \\
20 \\
21 \\
27 \\
26 \\
3 \cdot 3\end{array}$ & $\begin{array}{l}18 \\
31 \\
19 \\
12 \\
25 \\
22 \\
27 \\
22 \\
2 \cdot 6 \\
\text { NS }\end{array}$ & $\begin{array}{l}27 \\
25 \\
18 \\
40 \\
40 \\
35 \\
28 \\
30 \\
3 \cdot 3\end{array}$ & $\begin{array}{l}50 \\
50 \\
50 \\
50 \\
48 \\
44 \\
40 \\
47 \\
1.6 \\
<0.0025\end{array}$ & $\begin{array}{c}122 \\
116 \\
72 \\
- \\
92 \\
99 \\
80 \\
97 \\
8 \cdot 8\end{array}$ & $\begin{array}{c}114 \\
106 \\
84 \\
- \\
115 \\
103 \\
103 \\
104 \\
5 \cdot 0 \\
\text { NS }\end{array}$ & $\begin{array}{c}25 \\
30 \\
12 \\
24 \\
32 \\
32 \\
22 \\
25 \\
2 \cdot 9\end{array}$ & $\begin{array}{c}45 \\
42 \\
38 \\
26 \\
36 \\
38 \\
35 \\
37 \\
2.4 \\
<0.005\end{array}$ & $\begin{array}{c}30 \\
50 \\
22 \\
-16 \\
19 \\
21 \\
26 \\
5 \cdot 6\end{array}$ & $\begin{array}{c}17 \\
27 \\
12 \\
27 \\
19 \\
25 \\
21 \\
2 \cdot 7 \\
\text { NS }\end{array}$ & $\begin{array}{r}4312 \\
3964 \\
2673 \\
-\quad \\
994 \\
1972 \\
1318 \\
1540 \\
613\end{array}$ & $\begin{array}{c}5465 \\
3814 \\
3360 \\
- \\
1587 \\
2266 \\
1487 \\
2996 \\
684 \\
<0.025\end{array}$ \\
\hline
\end{tabular}

Abbreviations: $\mathrm{HR}$, heart rate in beats $/ \mathrm{min}$; CI, cardiac index ( $1 / \mathrm{min}$ per $\left.\mathrm{m}^{2}\right)$; SVI, stroke volume index (ml/m²); $\mathrm{MPA}$, mean pulmonary arterial pressure ( $\mathrm{mmHg})$; LVSP, mean left ventricular systolic pressure $(\mathrm{mmHg})$; LVEDP, left ventricular end-diastolic pressure (mmHg); LVSWI, left ventricular stroke work index $\left(\mathrm{g} \mathrm{m} / \mathrm{m}^{2}\right)$; TTI, tension-time index (mmHg-s/min); $\pm S E M$, standard error of mean; $P$, $P$ value; $R$, rest; E, exercise; NS, not significant.

Table 3 Effects of isosorbide dinitrate on resting haemodynamics

\begin{tabular}{|c|c|c|c|c|c|c|c|c|c|c|c|c|c|c|c|c|}
\hline \multirow{2}{*}{$\begin{array}{l}\text { Case } \\
\text { No. }\end{array}$} & \multicolumn{2}{|l|}{$H R$} & \multicolumn{2}{|l|}{$C I$} & \multicolumn{2}{|l|}{$S V I$} & \multicolumn{2}{|c|}{$M P A$} & \multicolumn{2}{|l|}{$L V S P$} & \multicolumn{2}{|c|}{$L V E D P$} & \multicolumn{2}{|c|}{$L V S W I$} & \multicolumn{2}{|l|}{$T T I$} \\
\hline & $\boldsymbol{R}$ & $R^{I}$ & $\boldsymbol{R}$ & $R^{I}$ & $\boldsymbol{R}$ & $R^{I}$ & $\boldsymbol{R}$ & $R^{I}$ & $\boldsymbol{R}$ & $R^{I}$ & $\boldsymbol{R}$ & $R^{I}$ & $\boldsymbol{R}$ & $R^{I}$ & $\boldsymbol{R}$ & $R^{I}$ \\
\hline $\begin{array}{l}1 \\
2 \\
3 \\
4 \\
5 \\
6 \\
7 \\
\text { Mean } \\
\pm \text { SEM } \\
\text { P }\end{array}$ & $\begin{array}{c}90 \\
70 \\
100 \\
90 \\
87 \\
96 \\
105 \\
91 \\
4.6\end{array}$ & $\begin{array}{c}87 \\
78 \\
100 \\
84 \\
80 \\
96 \\
110 \\
91 \\
4 \cdot 8 \\
\text { NS }\end{array}$ & $\begin{array}{l}2 \cdot 4 \\
3 \cdot 1 \\
2 \cdot 7 \\
2 \cdot 6 \\
2 \cdot 0 \\
2 \cdot 1 \\
2 \cdot 8 \\
2 \cdot 5 \\
0 \cdot 2\end{array}$ & $\begin{array}{l}2 \cdot 0 \\
2 \cdot 6 \\
2 \cdot 8 \\
1 \cdot 7 \\
1 \cdot 9 \\
2 \cdot 4 \\
2 \cdot 5 \\
2 \cdot 3 \\
0 \cdot 2 \\
\text { NS }\end{array}$ & $\begin{array}{c}27 \\
44 \\
27 \\
19 \\
23 \\
21 \\
27 \\
27 \\
3 \cdot 3\end{array}$ & $\begin{array}{c}23 \\
33 \\
16 \\
19 \\
24 \\
25 \\
23 \\
23 \\
2 \cdot 2 \\
\text { NS }\end{array}$ & $\begin{array}{l}25 \\
25 \\
18 \\
45 \\
45 \\
36 \\
28 \\
32 \\
4 \cdot 2\end{array}$ & $\begin{array}{l}15 \\
14 \\
18 \\
40 \\
28 \\
27 \\
20 \\
23 \\
3.8 \\
<0.0025\end{array}$ & $\begin{array}{c}142 \\
113 \\
72 \\
- \\
100 \\
101 \\
86 \\
102 \\
10 \cdot 7\end{array}$ & $\begin{array}{c}89 \\
91 \\
65 \\
85 \\
86 \\
85 \\
83 \\
4.2 \\
<0.025\end{array}$ & $\begin{array}{c}30 \\
30 \\
12 \\
26 \\
34 \\
27 \\
25 \\
26 \\
2 \cdot 8\end{array}$ & $\begin{array}{r}18 \\
8 \\
12 \\
17 \\
24 \\
22 \\
17 \\
17 \\
2.2 \\
<0.005\end{array}$ & $\begin{array}{c}41 \\
50 \\
22 \\
-21 \\
21 \\
22 \\
29 \\
5 \cdot 7\end{array}$ & $\begin{array}{c}22 \\
37 \\
12 \\
20 \\
22 \\
21 \\
22 \\
3.6 \\
<0.05\end{array}$ & $\begin{array}{r}4666 \\
3808 \\
2673 \\
- \\
1044 \\
1946 \\
1445 \\
2597 \\
630\end{array}$ & $\begin{array}{c}3055 \\
3741 \\
2592 \\
- \\
1088 \\
1816 \\
1496 \\
2298 \\
451 \\
\text { NS }\end{array}$ \\
\hline
\end{tabular}

Abbreviations: $\mathbf{R}$, rest; $\mathbf{R}^{I}$, rest after isosorbide. Other abbreviations are the same as for Table 2.

Table 4 Effects of isosorbide dinitrate on exercise haemodynamics

\begin{tabular}{|c|c|c|c|c|c|c|c|c|c|c|c|c|c|c|c|c|}
\hline \multirow{2}{*}{$\begin{array}{l}\text { Case } \\
\text { No. }\end{array}$} & \multicolumn{2}{|l|}{$H R$} & \multicolumn{2}{|l|}{$C I$} & \multicolumn{2}{|l|}{$S V I$} & \multicolumn{2}{|l|}{$M P A$} & \multicolumn{2}{|c|}{$L V S P$} & \multicolumn{2}{|c|}{$L V E D P$} & \multicolumn{2}{|c|}{$L V S W I$} & \multicolumn{2}{|l|}{$T T I$} \\
\hline & $E$ & $E^{I}$ & $E$ & $E^{I}$ & $E$ & $E^{I}$ & $E$ & $E^{I}$ & $E$ & $E^{I}$ & $E$ & $E^{I}$ & $E$ & $E^{I}$ & $E$ & $E^{I}$ \\
\hline $\begin{array}{l}1 \\
2 \\
3 \\
4 \\
5 \\
6 \\
7 \\
\text { Mean } \\
\pm \text { SEM } \\
\mathbf{P}\end{array}$ & $\begin{array}{r}135 \\
115 \\
130 \\
97 \\
115 \\
110 \\
120 \\
117 \\
5 \cdot 2\end{array}$ & $\begin{array}{c}135 \\
105 \\
120 \\
94 \\
120 \\
110 \\
130 \\
116 \\
5 \cdot 8 \\
N S\end{array}$ & $\begin{array}{l}2 \cdot 4 \\
3 \cdot 6 \\
2 \cdot 5 \\
1 \cdot 2 \\
2 \cdot 9 \\
2 \cdot 4 \\
3 \cdot 2 \\
2 \cdot 6 \\
0.3\end{array}$ & $\begin{array}{l}2 \cdot 7 \\
4 \cdot 2 \\
2 \cdot 6 \\
1 \cdot 6 \\
3 \cdot 5 \\
3 \cdot 3 \\
4 \cdot 1 \\
3 \cdot 1 \\
0 \cdot 4 \\
<0.0025\end{array}$ & $\begin{array}{c}18 \\
31 \\
19 \\
12 \\
25 \\
22 \\
27 \\
22 \\
2 \cdot 6\end{array}$ & $\begin{array}{c}20 \\
40 \\
22 \\
17 \\
29 \\
30 \\
32 \\
27 \\
3 \cdot 2 \\
<0.0025\end{array}$ & $\begin{array}{l}50 \\
50 \\
50 \\
50 \\
48 \\
44 \\
40 \\
47 \\
1.6\end{array}$ & $\begin{array}{l}20 \\
30 \\
16 \\
45 \\
48 \\
38 \\
32 \\
33 \\
4.9 \\
<0.0125\end{array}$ & $\begin{array}{c}114 \\
106 \\
84 \\
-\quad \\
115 \\
103 \\
103 \\
104 \\
5 \cdot 0\end{array}$ & $\begin{array}{c}128 \\
119 \\
65 \\
-112 \\
97 \\
104 \\
104 \\
9 \cdot 9 \\
\text { NS }\end{array}$ & $\begin{array}{c}45 \\
42 \\
38 \\
26 \\
36 \\
38 \\
35 \\
37 \\
2 \cdot 4\end{array}$ & $\begin{array}{c}20 \\
33 \\
15 \\
23 \\
33 \\
28 \\
28 \\
26 \\
2.7 \\
<0.01\end{array}$ & $\begin{array}{c}17 \\
27 \\
12 \\
27 \\
19 \\
25 \\
21 \\
2 \cdot 7\end{array}$ & $\begin{array}{c}29 \\
47 \\
15 \\
31 \\
28 \\
33 \\
30 \\
4.6 \\
<0.01\end{array}$ & $\begin{array}{r}5465 \\
3814 \\
3360 \\
- \\
1587 \\
2266 \\
1487 \\
2996 \\
624\end{array}$ & $\begin{array}{c}4838 \\
4614 \\
3087 \\
- \\
1619 \\
2343 \\
1888 \\
3065 \\
618 \\
\text { NS }\end{array}$ \\
\hline
\end{tabular}

Abbreviations: E, exercise; $\mathrm{E}^{I}$, exercise after isosorbide. Other abbreviations are the same as for Table 2.

dinitrate was a reduction in mean left ventricular end-diastolic pressure $(19 \%)$. A fall in left ventricular end-diastolic pressure was observed in all but one patient in whom it did not change. There was a corresponding fall in mean pulmonary arterial pressure (mean $28 \%$ ). There was a significant fall in mean left ventricular stroke work index $(24 \%)$ and mean left ventricular systolic pressure $(19 \%)$.
There were no significant changes in mean cardiac index or stroke volume index. Mean tension-time index did not change significantly.

Effects of isosorbide on exercise haemodynamics (Table 4)

Compared with the control exercise period there were significant increases in mean cardiac index 

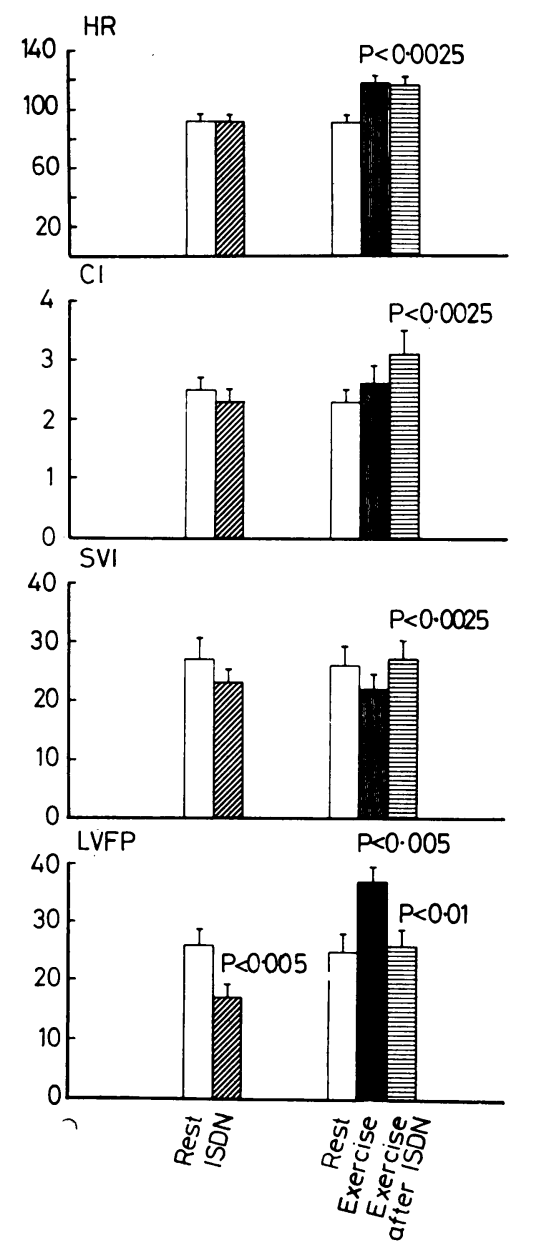

Fig. 1 Haemodynamic effects of isosorbide dinitrate. Mean values $(n=7)$ for heart rate $(H R)$ beats per minute; cardiac index $(C I) l /$ min per $\mathrm{m}^{2}$; stroke volume index $(S V I) \mathrm{ml} / \mathrm{m}^{2}$; left ventricular filling pressure (LVFP) $m m H g$. Bars represent standard error of the mean.

$(19 \%)$, stroke volume index $(23 \%)$, and left ventricular stroke work index (43\%). In association there were pronounced falls in mean left ventricular end-diastolic pressure $(19 \%)$ and mean pulmonary arterial pressure (mean $30 \%$ ). There were no significant changes in mean values for heart rate, mean left ventricular systolic pressure, and tensiontime index.

The effects of isosorbide dinitrate on haemodynamic variables are illustrated in Fig. 1 and 2.

\section{Discussion}

The most important cardiovascular stress is that of exercise. In ambulant patients with congestive

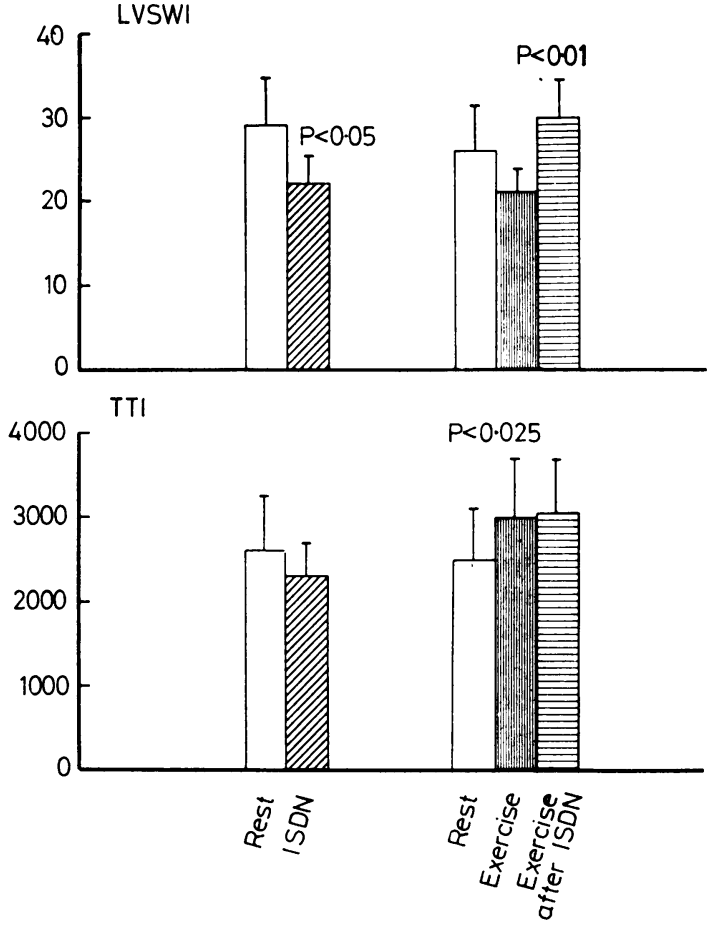

Fig. 2 Haemodynamic effects of isosorbide dinitrate.

Mean values $(n=7)$ for left ventricular stroke work index, $\mathrm{g} \mathrm{m} / \mathrm{m}^{2}$ and tension-time index (TTI) $\mathrm{mmHg} \mathrm{s} / \mathrm{min}$.

Bars indicate standard error of the mean.

cardiac failure a reduction in exercise tolerance caused by fatigue or dyspnoea constitutes their major disability. The response to exercise of the failing heart has been characterised by pronounced rises in left ventricular end-diastolic pressure together with a much diminished or even negative response in cardiac output, stroke volume, left ventricular stroke work, and left ventricular contractile state. This is in distinct contrast to the response of the normal heart where exercise is associated with increases in cardiac output, stroke volume, and stroke work with little or no increase in left ventricular end-diastolic pressure (Ross et al., 1966; Krayenbuehl et al., 1972).

The rise in left ventricular end-diastolic pressure may be regarded as a compensatory mechanism (Frank-Starling principle) in congestive cardiac failure, by which cardiac output is maintained. During exercise, however, this mechanism fails possibly because of the ventricle reaching the peak or entering the 'descending limb' of its Starling curve.

High levels of circulating noradrenalin have been observed in patients with congestive cardiac failure at rest and more strikingly during exercise compared 
with normals (Chidsey et al., 1962). Further, though myocardial noradrenalin stores are depleted in congestive cardiac failure (Chidsey et al., 1963), there is evidence that the failing heart is supersensitive to circulating noradrenalin (Spann et al., 1967). Thus, two further supportive mechanisms exist in congestive cardiac failure, tending on one hand to maintain systemic arterial pressure by augmentation of peripheral vascular tone, while on the other to augment myocardial contractility. However, these mechanisms may be inadequate or even deleterious during exercise. Though an increase in peripheral vascular tone preserves arterial pressure, this together with the reduced arterial compliance known to occur in congestive cardiac failure (Zelis et al., 1973) increases arterial impedance, that is left ventricular afterload (Milnor, 1975). This increase in afterload is poorly tolerated by the failing left ventricle, resulting in a further rise in left ventricular filling pressure, systolic wall tension and thus myocardial oxygen consumption. This chain of events would tend to oppose the inotropic effects of circulating catecholamines.

The rationale of treating congestive cardiac failure with vasodilators is primarily to reduce left ventricular afterload according to Cohn (1973). A fall in left ventricular end-diastolic pressure appears to be the most commonly observed response to vasodilators. This may result from improved ejection fraction or from reduced venous return, as vasodilators have been shown to produce venodilatation as well as arteriolar dilatation (Mason and Braunwald, 1965). Reported changes in cardiac output and left ventricular stroke work have however been variable. While improvement has been observed in some patients, falls have been observed in others (Chatterjee et al., 1973; Williams et al., 1977). The latter may be related to a reduction of left ventricular end-diastolic pressure below optimal levels (Crexells et al., 1973).

The present study shows the characteristic haemodynamic responses to exercise of patients in congestive cardiac failure discussed above. Mild exertion produced large increases in left ventricular end-diastolic pressure with no significant change in cardiac index, stroke volume index, left ventricular stroke work index, or mean left ventricular systolic pressure. A significant rise in tension-time index suggests, however, an increase in myocardial oxygen consumption (Sarnoff et al., 1957).

After the administration of isosorbide dinitrate at rest, distinct falls in left ventricular end-diastolic pressure were observed. Other aspects of left ventricular performance however were not uniformly improved. Indeed, there were falls in cardiac index and left ventricular stroke work index in some

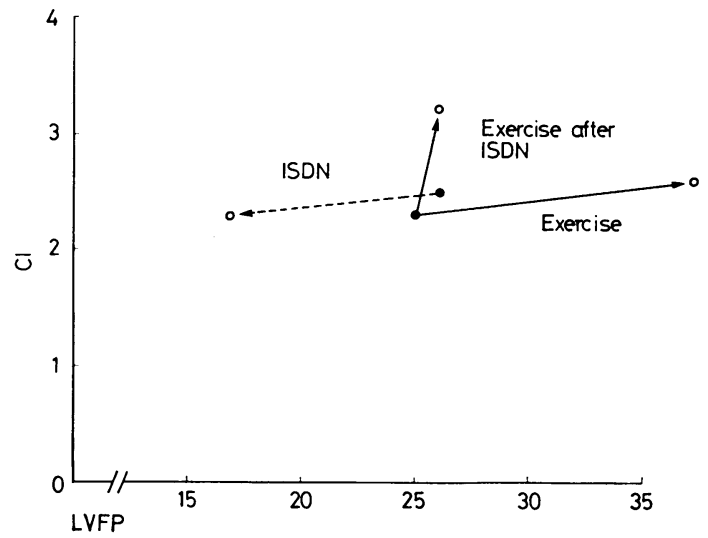

Fig. 3 Relation between left ventricular filling pressure (LVFP) $\mathrm{mmHg}$ and cardiac index (CI) $l / \mathrm{min}$ per $\mathrm{m}^{2}$. The values indicated are mean values $(n=7)$. The arrows indicate the direction of change from control (pre-isosorbideclosed circles) to the intervention indicated (open circles).

patients. In contrast, isosorbide dinitrate produced a more comprehensive improvement in left ventricular performance during exercise (Fig. 3). A possible explanation for these observations is that isosorbide dinitrate reduces left ventricular enddiastolic pressure (preload) to below optimal levels at rest but that an optimal level is achieved during exercise by an increase in venous return. The parallel reduction in afterload decreases left ventricular wall tension and increases left ventricular ejection fraction. Inotropic stimulation by circulating catecholamine may now act to augment left ventricular performance.

These changes would have variable effects on myocardial oxygen consumption. For example, decreased wall tension would reduce myocardial oxygen consumption while increased contractility would have the opposite effect (Graham et al., 1968). It is of interest to observe that the improvement in exercise left ventricular performance by isosorbide dinitrate was achieved without further increase in the tension-time index, suggesting that these influences were balanced with respect to myocardial oxygen demand.

Improved regional myocardial blood supply (Becker et al., 1971; Horwitz et al., 1971) may be an additional factor in the observed improvement in exercise haemodynamics after isosorbide dinitrate administration, since all patients had coronary artery disease as the primary disorder.

The results of this study stress the need for caution in the use of isosorbide dinitrate in the treatment of the patient confined to bed with congestive cardiac failure. Although pulmonary congestion 
may be effectively relieved through the lowering of the left ventricular end-diastolic pressure, perfusion of vital organs, such as kidneys and brain, may be compromised by further reduction in cardiac output. In patients with severe impairment of left ventricular function where such considerations may be important, careful haemodynamic assessment of the individual's response to isosorbide dinitrate is, therefore, desirable. The effects of isosorbide dinitrate on exercise haemodynamics, however, provides evidence that long-term treatment with this agent may be effective in improving exercise tolerance in ambulant patients with chronic congestive cardiac failure, making a useful alternative to the use of digitalis glycosides which have been shown to produce only a modest overall improvement in cardiac function at rest and during exercise (Cohn et al., 1975).

\section{References}

Becker, L. C., Fortuin, N. J., and Pitt, B. (1971). Effect of ischaemia and antianginal drugs on the distribution of radioactive microspheres in the canine left ventricle. Circulation Research, 28, 263-269.

Bussmann, W. D., Löhner, J., and Kaltenbach, M. (1977). Orally administered isosorbide dinitrate in patients with and without left ventricular failure due to acute myocardial infarction. American fournal of Cardiology, 39, 91-96.

Chatterjee, K., Parmley, W. W., Ganz, W., Forrester, J., Walinsky, P., Crexells, C., and Swan, H. J. C. (1973). Hemodynamic and metabolic responses to vasodilator therapy in acute myocardial infarction. Circulation, 48, 1183-1193.

Chidsey, C. A., Braunwald, E., Morrow, A. G., and Mason, D. T. (1963). Myocardial norepinephrine concentration in man. New England fournal of Medicine, 269, 653-658.

Chidsey, C. A., Harrison, D. C., and Braunwald, E. (1962). Augmentation of the plasma nor-epinephrine response to exercise in patients with congestive heart failure. New England fournal of Medicine, 267, 650-654.

Cohn, J. N. (1973). Vasodilator therapy for heart failure-the influence of impedance on left ventricular performance. Circulation, 48, 5-7.

Cohn, K., Selzer, A., Kersh, E. S., Karpman, L. S., and Goldschlager, N. (1975). Variability of hemodynamic responses to acute digitalization in chronic cardiac failure due to cardiomyopathy and coronary artery disease. American fournal of Cardiology, 35, 461-468.

Crexells, C., Chatterjee, K., Forrester, J. S., Dikshit, K., and Swan, H. J. C. (1973). Optimal level of filling pressure in the left side of the heart in acute myocardial infarction. New England fournal of Medicine, 289, 1263-1266.

Franciosa, J. A., Mikulic, E., Cohn, J. N., Jose, E., and Fabie, A. (1974). Hemodynamic effects of orally administered isosorbide dinitrate in patients with congestive heart failure. Circulation, 50, 1020-1024.

Ganz, W., and Swan, H. J. C. (1972). Measurement of blood flow by thermodilution. American fourna! of Cardiology, 29, 241-246.

Gold, H. K., Leinbach, R. C., and Sanders, C. A. (1972). Use of sublingual nitroglycerin in congestive failure following acute myocardial infarction. Circulation, 46, 839-845.

Graham, T. P., Covell, J. W., Sonnenblick, E. H., Ross, J., Jr., and Braunwald, E. (1968). Control of myocardial oxygen consumption: relative influence of contractile state and tension development. Fournal of Clinical Investigation, 47, 375-385.

Gray, R., Chatterjee, K., Vyden, J. K., Ganz, W., Forrester, J. S., and Swan, H. J. C. (1975). Hemodynamic and metabolic effects of isosorbide dinitrate in chronic congestive heart failure. American Heart fournal, 90, 346-352.

Guiha, N. H., Cohn, J. N., Mikulic, E., Franciosa, J. A., and Limas, C. J. (1974). Treatment of refractory heart failure with infusion of nitroprusside. New England fournal of Medicine, 291, 587-592.

Horwitz, L. D., Gorlin, E., Taylor, W. J., and Kemp, H. G. (1971). Effects of nitroglycerin on regional myocardial blood flow in coronary artery disease. Fournal of Clinical Investigation, 50, 1578-1584.

Krayenbuehl, H. P., Rutishauser, W., Schoenbeck, M., and Amende, I. (1972). Evaluation of left ventricular function from isovolumic pressure measurements during isometric exercise. American fournal of Cardiology, 29, 323-330.

Majid, P. A., Sharma, B., and Taylor, S. H. (1971). Phentolamine for vasodilator treatment of severe heart failure. Lancet, 2, 719-724.

Mason, D. T., and Braunwald, E. (1965). The effects of nitroglycerin and amyl nitrate on arteriolar and venous tone in the human forearm. Circulation, 32, 755-766.

Miller, R. R., Vismara, L. A., Zelis, R., Amsterdam, E. A., and Mason, D. T. (1975). Clinical use of sodium nitroprusside in chronic ischaemic heart disease-effects on peripheral vascular resistance and venous tone and on ventricular volume, pump and mechanical performance. Circulation, 51, 328-336.

Milnor, W. R. (1975). Arterial impedance as ventricular afterload. Circulation Research, 36, 565-570.

Mullins, C. B., Leshin, S. J., Mierzwiak, D. S., Alsobrook, H. D., and Mitchell, J. H. (1972). Changes in left ventricular function produced by the injection of contrast media. American Heart fournal, 83, 373-381.

Ross, J., Jr., Gault, J. H., Mason, D. T., Linhart, J. W., and Braunwald, E. (1966). Left ventricular performance during muscular exercise in patients with and without cardiac dysfunction. Circulation, 34, 597-608.

Rossen, R. M., Alderman, E. L., and Harrison, D. C. (1976). Circulatory response to vasodilator therapy in congestive cardiomyopathy. British Heart fournal, 38, 695-700.

Sandler, H., and Dodge, H. T. (1968). The use of single plane angiocardiograms for the calculation of left ventricular volume in man. American Heart fournal, 75, 325-334.

Sarnoff, S. J., Braunwald, E., Welch, G. H., Case, R. B., Stainsby, W. N., and Macruz, R. (1957). Hemodynamic determinants of oxygen consumption of the heart with special reference to the tension-time index. American fournal of Physiology, 192, 148-156.

Spann, J. E., Jr., Buccino, R. A., Sonnenblick, E. H., and Braunwald, E. (1967). Contractile state of cardiac muscle obtained from cats with experimentally produced ventricular hypertrophy and heart failure. Circulation Research, 21, 341-354.

Williams, D. O., Bommer, W. J., Miller, R. R., Amsterdam, E. A., and Mason, D. T. (1977). Hemodynamic assessment of oral peripheral vasodilator therapy in chronic congestive heart failure: prolonged effectiveness of isosorbide dinitrate. American fournal of Cardiology, 39, 84-90.

Zelis, R., Longhurst, J., Capone, R. J., and Lee, G. (1973). Peripheral circulatory control mechanisms in congestive heart failure. American fournal of Cardiology, 32, 481-490.

Requests for reprints to Dr J. Stephens, Department of Cardiology, St. Bartholomew's Hospital, London EC1A 7BE. 